\title{
Basal cell carcinoma: an updated epidemiological and therapeutically profile of an urban population ${ }^{1}$
}

\author{
Carcinoma basocelular: perfil epidemiológico e \\ terapêutico de uma população urbana
}

\author{
Roberta Lopes Bariani², Fábio Xerfan Nahas ${ }^{3}$, Marcus Vinícius Jardini Barbosa ${ }^{4}$, Andréia Bufoni Farah ${ }^{5}$, \\ Lydia Masako Ferreira ${ }^{6}$
}

1. Plastic Surgery Residence Program at the Hospital Jaraguá (São Paulo) and Federal University of São Paulo (UNIFESP), Brazil.

2. Plastic Surgeon member of the Brazilian Society of Plastic Surgery. Brazil.

3. Associate Professor of the Division of Plastic Surgery -UNIFESP-EPM. Brazil.

4. Plastic Surgeon, Master Degree in Medicine of UNIFESP. Brazil.

5. Plastic Surgeon, Master Degree in Medicine of UNIFESP. Brazil.

6. Full Professor of the Division of Plastic Surgery of UNIFESP. Brazil.

\begin{abstract}
Purpose: To describe the epidemiological profile of basal cell carcinoma patients at a private hospital in São Paulo and to evaluate the treatment adopted. Methods:A prospective study of 202 patients, on which 253 lesions were diagnosed for histopathological exam as basal cell carcinoma within the period of January 2001 to September 2003, in the Plastic Surgery Residency Program at the Hospital Jaraguá. The susceptibility factor of the host, the environment variables, the characteristics of the lesions and the efficacy of the treatment were examined. The data were statistically evaluated. Results:The incidence of basal cell carcinoma was 126 cases per 100,000 patients in a period of 32 months (36 cases per 100,000 patients/year). The patients were evenly distributed in terms of sex: $48 \%$ male and 52\% female. The greater incidence was in patients between the ages of 60 and 80 years and the average was 64 years. The survey revealed susceptibility factors such as white race and phototypes I and II in $95.5 \%$ of the patients. Exposition to ultraviolet radiation was reported by $77 \%$ of the patients and the most frequent location of tumors was on the face (71.2\% of the cases). Actinic keratosis and a history of skin cancer were reported in $43.6 \%$ and in $25 \%$ of the cases, respectively. The adopted treatment was surgery in $99.4 \%$ of the cases and only one patient was treated with radiotherapy. Twenty lesions (8\%) had incomplete excision. The recurrence rate was $2 \%$ (5 cases). There were no cases with metastasis or fatal outcome. Conclusions: The factors related to the development of basal cell cancer which were significantly present in the population surveyed were: older age, white individuals, phototypes I and II, presence of actinic keratosis, previous history of non-melanoma skin cancer and exposure to ultra-violet rays both in recreational and in occupational form.The surgical treatment employed was effective with a rate of incomplete excision and recurrence similar to those found in the literature.
\end{abstract}

Key words: Neoplasms, Basal Cell. Skin Neoplasms. Epidemiologic Studies. Urban Population.

\section{RESUMO}

Objetivo:Traçar o perfil epidemiológico dos portadores de carcinoma basocelular e avaliar o tratamento instituído no Serviço de Residência de Cirurgia Plástica do Hospital Jaraguá. Métodos: Foi realizado um estudo prospectivo de 202 pacientes, nos quais foram diagnosticados 253 lesões por exame anátomo-patológico como carcinoma basocelular no período de janeiro de 2001 a setembro de 2003, no Serviço de Residência de Cirurgia Plástica do Hospital Jaraguá. Foram abordados fatores de susceptibilidade do hospedeiro, fatores ambientais, características das lesões, o tratamento instituído e sua eficácia. Os dados encontrados foram submetidos à análise estatística. Resultados: A incidência de carcinoma basocelular encontrada foi de 126 casos/ 100.000 pacientes em 32 meses (36casos/100.000 pacientes/ano). Os pacientes se distribuíram de forma semelhante entre os sexos masculino (48\%), e feminino (52\%), com uma incidência maior na faixa etária entre 60 e 80 anos (69\%), com média de 64,0 anos. A amostra apresentou fatores de susceptibilidade como a raça branca e fototipos I e II em 95,5\% dos pacientes. A exposição à radiação ultravioleta foi informada por $77 \%$ dos pacientes, e a localização mais freqüente dos tumores foi a face, em 71,2\% dos casos. A ceratose actínica e a história de câncer de pele anterior estavam presentes em 43,6\% e 25,8\%, respectivamente. O tratamento instituído foi o cirúrgico em 99,4\% dos casos, sendo que um caso foi tratado com radioterapia por falta de condições clínicas. No anátomo-patológico foram encontradas 20 lesões (8\%) com margens comprometidas pelo tumor. A taxa de recidiva no acompanhamento pós-operatório foi de 2\% (5 casos). Não houve casos de metástase ou óbito. Conclusões: Os fatores relacionados ao desenvolvimento do carcinoma basocelular que estão presentes de forma significante na população estudada são: idade avançada,raça branca, fototipos I e II, presença de ceratose actínica, história anterior de câncer de pele não-melanoma e exposição aos raios ultra- 
violetas tanto de forma recreacional quanto ocupacional.O tratamento instituído foi efetivo com taxas de margens comprometidas e recidivas comparáveis com as da literatura.

Descritores: Neoplasia de Células Basais. Neoplasias Cutâneas. Estudos Epidemiológicos. População Urbana.

\section{Introduction}

The incidence of skin cancer has been increasing in great proportions, especially in tropical countries. ${ }^{1}$ It was estimated that 2.75 million new cases of non- melanoma skin cancer (NMSC) are diagnosed every year all over the world ${ }^{2}$. The American Skin Cancer Foundation estimates that one in every six Americans will develop this type of cancer in their lifetimes ${ }^{3,4}$. In Brazil, the National Cancer Institute estimated that in 2003 the NMSC will continue to be the main type of cancer to affect the Brazilian population. In São Paulo city itself there is an annual incidence of 29.265 new cases of this type of cancer ${ }^{5}$. NMSC are divided into two main histological types : the basal cell carcinoma (BCC) and squamous cell carcinoma (SCC). Considering all NMSC, $75 \%$ of them correspond to BCC whereas $20 \%$ are SCC ${ }^{3,6}$. The incidence of BCC is very high all over the world, especially in regions close to the Equator ${ }^{3,7}$ and in fairskinned individuals with previous history of solar exposure ${ }^{6}$. The importance of NMSC as a public health problem has been underestimated mainly due to its good prognosis when detected and treated precociously, having a low mortality rate ${ }^{8}$. It can, however, evolve with considerable morbidity and may be even fatal when well advanced. The purpose of this paper is to describe the epidemiological profile of the Basal Cell Carcinoma, identifying the factors related to the development of this condition and evaluate the treatment carried out in a service treating private patients in the city of São Paulo.

\section{Methods}

Between January 2001 and September 2003, 202 patients with 253 neoplasias diagnosed as basal cell carcinoma through histopathological exam were studied prospectively. The population under study was treated by the Plastic Surgery Residency Program medical team at the Hospital Jaraguá. This hospital is responsible for the health care of a population of 200,865 private patients. The age distribution of this group is shown in Table 1 on which $45.59 \%$ of these patients were males and $54.41 \%$ were females.

TABLE 1 - Distribution of individuals who have medical care provided by the Hospital Jaraguá and the population of the city of São Paulo, according to age range

\begin{tabular}{ccc}
\hline $\begin{array}{c}\text { Age group } \\
\text { (years) }\end{array}$ & $\begin{array}{c}\text { Population of } \\
\text { São Paulo city } \\
\text { (\%) }\end{array}$ & $\begin{array}{c}\text { Population with health } \\
\text { care at Hospital Jaraguá } \\
\text { (\%) }\end{array}$ \\
\hline $30-39$ & 34.83 & 38.36 \\
$40-49$ & 27.71 & 28.22 \\
$50-59$ & 17.53 & 17.32 \\
$60-69$ & 11.06 & 10.19 \\
$70-79$ & 6.47 & 4.70 \\
$>80$ & 2.39 & 1.21 \\
\hline
\end{tabular}

The epidemiological characteristics of this population were analyzed according to the individual susceptibility of the patient, environmental conditions and characteristics of the lesions. These data were collected by the author using a questionnaire. The types of treatment and their efficacy were also evaluated. Characteristics of the patient such as age, sex, race (white, black, mulatto, asian) and phototype according to Fitzpatrick's classification ${ }^{9}$ were also analyzed. Factors of individual predisposition such as the presence of genetic syndromes related to a greater incidence of skin cancer, actinic keratosis, previous history of skin cancer, causal factors of the decreasing of immunity such as neoplasic illnesses, use of immunosuppressants and organ transplantation were also investigated. Environmental factors such as exposure to ultraviolet radiation and type of exposure (in working or leisure time), exposure to ionic radiation and to chemical agents were also analyzed. Patients were asked about their exposure to the sun and were classified as exposed and not exposed. The exposed patients were those with prolonged exposure to solar radiation as during outdoor work or those who had history of sunburns with frequency during outdoor activities on holidays, weekends and sports. Characteristics of the lesion and length of evolution from the time elapsed between its perception and the consultation with a doctor as well as the symptoms of the lesion were questioned. The macroscopy and the location were described by the junior author (R.L.B.). The tumor was measured with a ruler and its largest diameter was registered. Previous treatment such as surgery, radiotherapy, local chemotherapy and others were also investigated. Patients who presented lesions with difficult clinical diagnosis or lesions which could cause deformity if removed within the preconized margins were submitted to incisional biopsy, so that a histological evaluation could confirm the diagnosis. The other cases were submitted to resection of the tumor, followed by reconstruction. The surgical margins were defined according to size, macroscopy and location of the lesion. Lesions under $20 \mathrm{~mm}$ were excised with a $3 \mathrm{~mm}$ margins if the tumor presented well-defined edges such as the nodular type or $5 \mathrm{~mm}$ margins if the tumor had poorly defined edges such as the infiltrative and superficial types. In lesions larger than $20 \mathrm{~mm}$, the margin utilized was over $5 \mathrm{~mm}$. Primary suture was the first option, followed by graft or flap, depending on the surgeon's indication. In patients with poor clinical condition, radiotherapy was indicated. Surgical procedures were carried out in the outpatient facility. Only patients who had clinical indication for monitoring and those who needed frozen biopsy were operated at the operating room in the hospital environment. Frozen biopsy was indicated in lesions on which resection involved a functional risk, also in cases of reoperation of incomplete excision and infiltrative lesions. All specimens were submitted to a histopathological exam and only those which were diagnosed as basal cell carcinoma were considered in this study. The efficacy of the treatment was evaluated 
according to the results of the margins in histopathological exams, depending on the presence of tumor in the skin edges. The incidence of recurrence was also investigated in the three-month and one-year follow up and, after that, the patient was seen every six months. Chi-squared test was used to verify the association between the qualitative variables and those of Mann-Whitney test, in order to check if there was a difference between the average of independent and continuous variables. Spearman correlation tests were also applied. The level of statistical significance used in the results was $\mathrm{p} \leq 0.05$. The software Statistica version 5.1 was used for all the analysis.

\section{Results}

Along the period of 32 months, 202 patients had 253 basal cell carcinoma among the 200.865 patients surveyed. Therefore, the incidence of this type of cancer in the population was approximately 126 cases for 100.000 patients in this period. Therefore,the annual incidence was 36 cases per 100.000 patients.

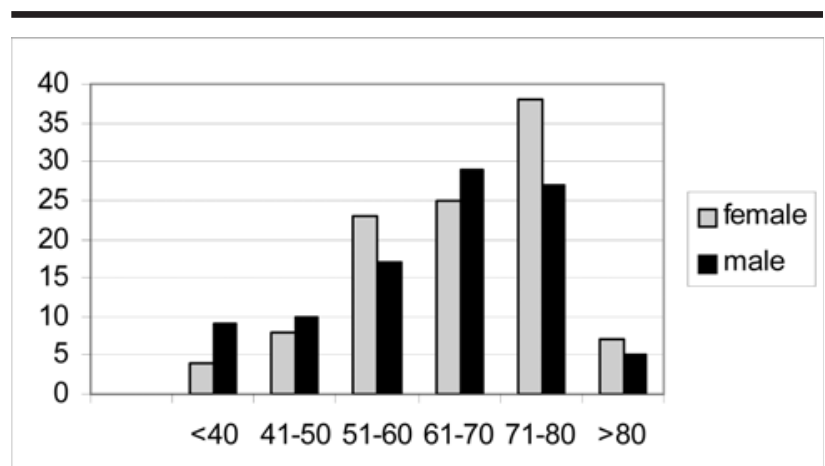

FIGURE 1 - Age distribution of patients according to sex

\section{Host factors}

The distribution of the patients according to sex was similar, being $52 \%$ female and $48 \%$ male, with a greater incidence in the age range of 60 to 80 (59\%) (Figure 1). The average age of the patients with BCC was 64.04, varying from 26 to 90 years old. The average age of the women was 65.4 and 62.5 for men. There was no statistically significant difference when the distribution of age was compared between the male and female groups (Table 2). One hundred and three patients were white (95.5\%), seven (3.5\%) were mullatos and only two were Asians (1\%). The majority of the patients was classified as phototype I and II (95.5\%) according to Fitzpatrick 's classification (Figure 2). Fifty two patients $(25.8 \%)$ had a previous history of skin carcinoma. In the physical exam, 88 patients (43.6\%) presented actinic keratosis, and 22 patients (10.9\%) presented both: previous history of skin cancer and actinic keratosis. Seven patients had another malignant neoplasia, one patient had mielofibroplasia, and another had a previous kidney transplantation.

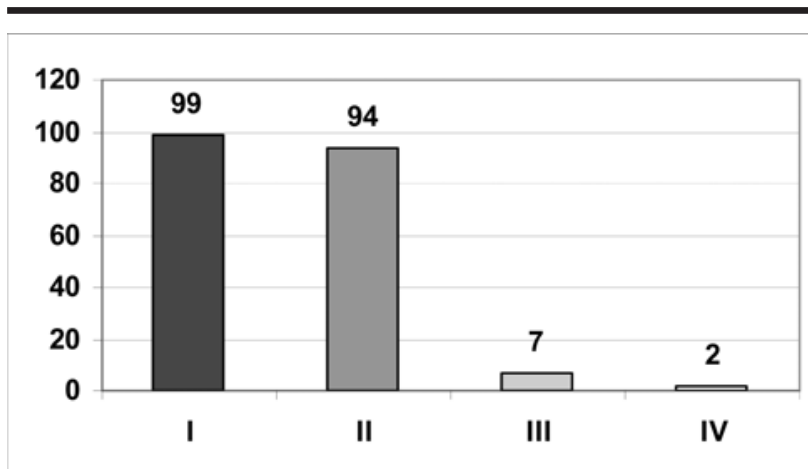

FIGURE 2 - Distribution of patients according to phototypes

TABLE 2 - Comparison of the average age between male and female patients with BCC

\begin{tabular}{lllllll}
\hline Variable & Sex & N & Average & \multicolumn{2}{c}{ U MannWhitney Test } & Pvalue \\
& & & & U & Z & \\
\hline Age & Female & 105 & 65.45 & 4472.5 & -1.49 & 0.13 \\
& Male & 97 & 62.52 & & & \\
\hline
\end{tabular}

\section{Environmental factors}

A hundred and fifty six patients (77.2\%) had a positive history of solar exposure (ultra violet radiation). Among these, 91 (58.3\%) had had occupational exposure and 65 patients (41.7\%) had had leisure exposure (Figure 3$)$. There was no statistically significant difference when patient's sex was considered for solar exposure. (Table 3).

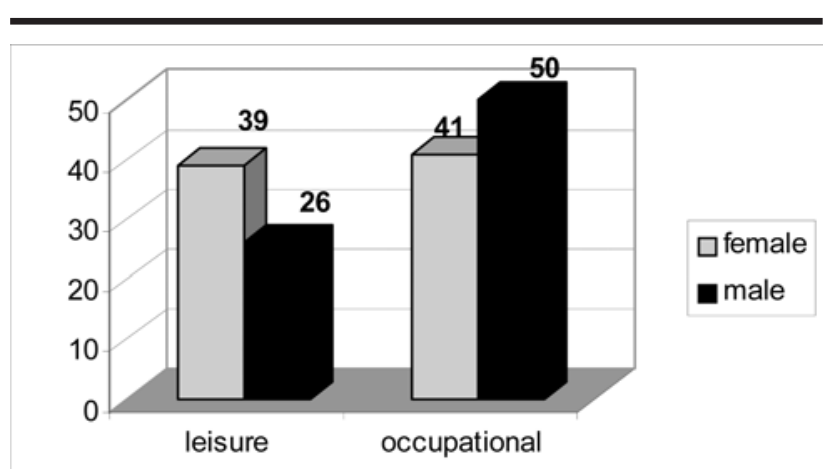

FIGURE 3 - Patients with intense solar exposure distributed according to the type of solar exposure and sex 
TABLE 3 - Comparison between male and female patients who had intensive solar exposure

\begin{tabular}{|c|c|c|c|c|c|}
\hline \multirow[t]{2}{*}{ Variable } & \multirow[t]{2}{*}{ Category } & \multicolumn{2}{|c|}{ Exposition } & \multirow[t]{2}{*}{ Test $\chi^{2}$} & \multirow[t]{2}{*}{ Value of $\mathrm{p}$} \\
\hline & & Yes & No & & \\
\hline \multirow[t]{2}{*}{ Sex } & Female & 80 & 25 & 0.13 & 0.71 \\
\hline & Male & 76 & 21 & & \\
\hline Total & & 156 & 46 & & \\
\hline
\end{tabular}

\section{Characteristics of the BCC}

In the two hundred and two patients, 253 BCC were found. The great majority of the patients presented only one tumor (82.2\%) (Table 4). Macroscopically the BCC were diagnosed as nodular in 118 tumors (47\%) (Figure 4). The average of the largest diameter of the BCC was $9.54 \mathrm{~mm}$, varying from 3 to $40 \mathrm{~mm}$. The greater incidence ranged from 6 to $15 \mathrm{~mm}$, representing 149 cases (58.9\%) (Table 5). The average time elapsed between the initial growth of the lesion reported by the patient and the moment on which the patient searched for medical evaluation was 19.8 months, ranging from one to 120 months (Table 6). In most of the cases the tumors were located in the cephalic segment and the remaining ones were distributed according to Figure 5. The most frequent location of the tumors in the cephalic segment was the nose for both sexes (Table 7). The symptoms that prompted patients to look for a doctor were identified in 167 patients and are described in Figure 6. In 218 cases (86.2\%), there had been no previous medical treatment. However, 17 cases (6.7\%) had previously undergone surgery (recurrent BCC) and 18 cases (7.1\%) had undergone another previous treatment, as shown on Figure 7. Incision biopsy was carried out in 16 (3\%) of the cases. The chosen treatment was surgery in $99.6 \%$ of the cases, and only one case was treated with radiotherapy $(0.4 \%)$ due to lack of clinical conditions (Table 8). The histopathological exam revealed 20 BCC (8\%) incompletely excised. The excision was incomplete at the lateral margin in $40 \%$, at the deep margin in $35 \%$ and at both in $25 \%$. Among the patients with incomplete excision, eight cases were reoperated (40\%) and the other 12 cases (60\%) have either been scheduled for another surgery or gave up treatment. In one of the eight cases of reoperation no tumor evidence was found. In the other seven cases, the specimen revealed BCC with margins free of tumor. Most of the BCC with incomplete excision were located on the nose (65\%) (Figure 8). The tumors that presented positive surgical excision margins varied between 3 and $10 \mathrm{~mm}$. Seventeen of these cases (85\%) were histologically diagnosed as nodular and as morphoeic in only three cases. The average time of evolution of the BCC in this group was 16.4 months. When this value was compared with the time of evolution of the BCC of the complete excision group, there was no statistically significant difference. The recurrence rate in the post-surgical follow up was $2 \%$ (5 cases).

TABLE 4 - Number of BCC per patient according to sex

\begin{tabular}{|c|c|c|c|c|c|c|}
\hline \multirow{2}{*}{$\begin{array}{c}\text { Number of } \\
\text { BCC }\end{array}$} & \multicolumn{2}{|c|}{ Female } & \multicolumn{2}{|c|}{ Male } & \multicolumn{2}{|c|}{ Total } \\
\hline & $\bar{n}$ & $\%$ & $\mathbf{n}$ & $\%$ & $\mathbf{N}$ & $\%$ \\
\hline 1 & 88 & 43.6 & 78 & 38.5 & 166 & 82.1 \\
\hline 2 & 13 & 6.4 & 12 & 6 & 25 & 12.4 \\
\hline 3 & 3 & 1.5 & 5 & 2.5 & 8 & 4 \\
\hline$\geq 4$ & 1 & 0.5 & 2 & 1 & 3 & 1.5 \\
\hline Total & 105 & 52 & 97 & 48 & 202 & 100 \\
\hline
\end{tabular}

Where: BCC- basal cell carcinoma

Table 4. Distribution of BCC according to its size
It occurred between 2 and 22 months after the surgery. The place of recurrence was heterogeneously distributed, as shown in Figure 9. There were no cases of metastasis or death.

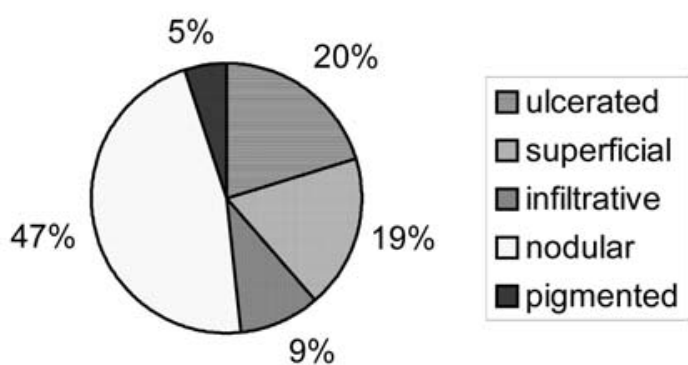

FIGURE 4 - Distribution of the BCC according to the macroscopic diagnosis

TABLE 5 - Distribution of BCC according to its size

\begin{tabular}{cll}
\hline Diameter $(\mathbf{m m})$ & $\boldsymbol{N}$ & $\boldsymbol{\%}$ \\
\hline $0-5$ & 77 & 30.4 \\
$6-15$ & 149 & 58.9 \\
$>15$ & 27 & 10.7 \\
Total & 253 & 100 \\
\hline
\end{tabular}

TABLE 6 - Distribution of cases according to the period of time between the occurrence of the BCC and the moment on which the patient searched for medical care

\begin{tabular}{cll}
\hline Evolution Time (months) & $\boldsymbol{N}$ & \% \\
\hline $1-12$ & 147 & 58.1 \\
$13-24$ & 69 & 27.3 \\
$25-36$ & 11 & 4.3 \\
$37-48$ & 6 & 2.4 \\
$>48$ & 20 & 7.9 \\
Total & 253 & 100 \\
\hline
\end{tabular}

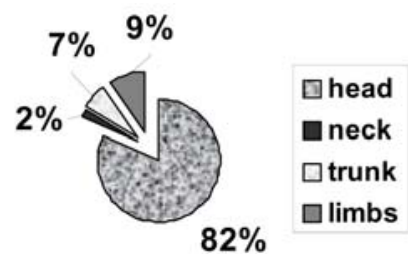

FIGURE 5 - Distribution of BCC according to its location

TABLE 7 - Distribution of cases in the cephalic segment according to the gender

\begin{tabular}{lllll}
\hline \multirow{2}{*}{ Region } & \multicolumn{2}{c}{ Female } & \multicolumn{2}{c}{ Male } \\
& $\boldsymbol{n}$ & \% & $\boldsymbol{n}$ & \% \\
\hline Forehead and temporal & 15 & 14.7 & 19 & 20.0 \\
Nasal & 45 & 44.1 & 31 & 32.6 \\
Zigomatic & 32 & 31.4 & 19 & 20.0 \\
Eyelid & 6 & 5.9 & 7 & 7.4 \\
Auricular & 2 & 2.0 & 12 & 12.6 \\
Labial & 1 & 1.0 & 2 & 2.1 \\
Mandibular & 1 & 1.0 & 5 & 5.3 \\
\hline Total & 102 & 100 & 95 & 100 \\
\hline
\end{tabular}




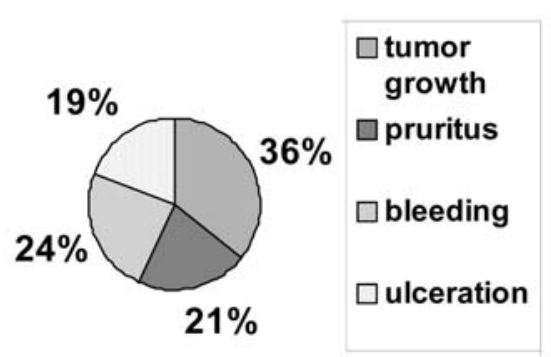

FIGURE 6 - Incidence of symptoms that led patients to look for medical care

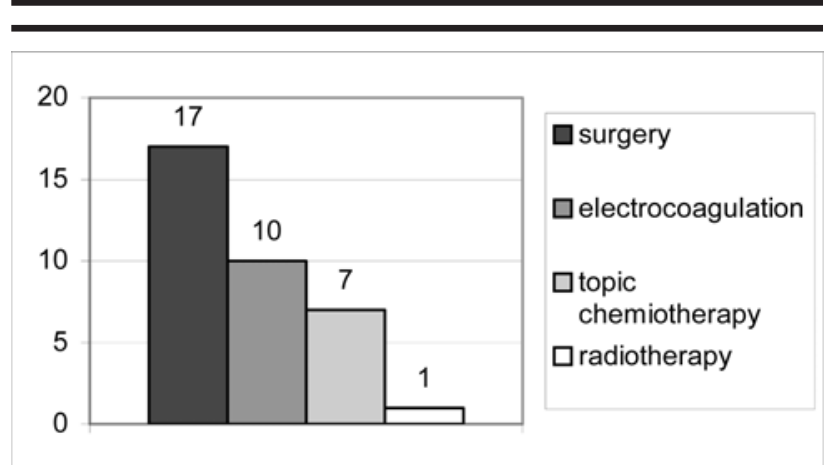

FIGURE 7 - Distribution of cases previously treated according to the type of treatment performed

TABLE 8 - Distribution of type of treatment of the BCC

\begin{tabular}{lll}
\hline Type of Treatment & \multicolumn{2}{c}{ Frequency } \\
& $\boldsymbol{n}$ & \% \\
\hline Excision + primary suture & 221 & 87.4 \\
Excision + graft & 7 & 2.8 \\
Excision + flap & 24 & 9.5 \\
Radiotherapy & 1 & 0.4 \\
\hline Total & 253 & 100.0 \\
\hline
\end{tabular}

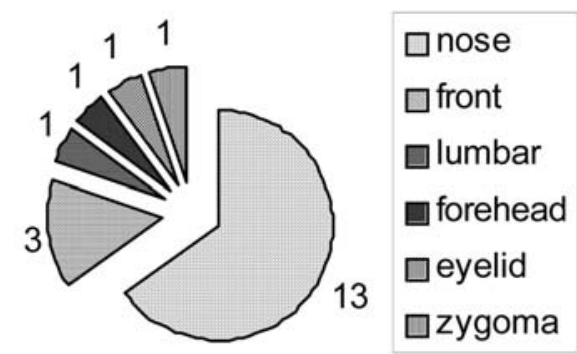

FIGURE 8 - Site of occurrence of BCC with incomplete excision

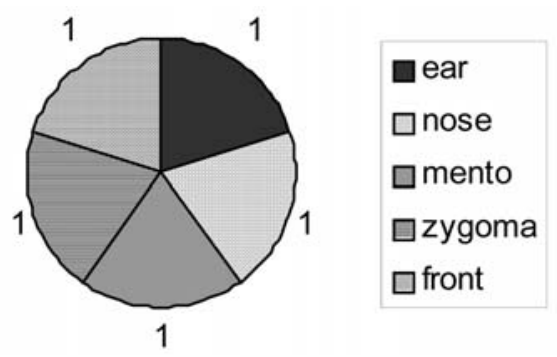

FIGURE 9 - Site of recurrent BCC

\section{Discussion}

Basal Cell Carcinoma is the most common type of skin cancer. It is the most common malignant tumor among white individuals ${ }^{10}$. In Brazil the incidence rate should be analyzed with caution since the national population database is not generally available. The treatment of BCC is carried out mainly in outpatient facilities or in private clinics, making the notification to the national cancer register more difficult ${ }^{11}$. The place with the highest incidence rate of nonmelanoma skin cancer is Queensland, in Australia, with an incidence of de 2.389/100.000 men and 1.908/100.000 women ${ }^{1}$. In Blumenau (a Brazilian city with a large population with German origin), between 1980 and 1990, the annual rate of CPNM was 330/100.000 inhabitants ${ }^{12}$. In the population treated at Hospital Jaraguá (São Paulo), the annual incidence of BCC was 36/100.000 patients less than expected when compared to the values estimated for the year 2003 by the National Cancer Institute that was 196/100.000 inhabitants for Southeast region of Brazil ${ }^{5}$ (in the same region where the city of São Paulo is located). In the last few years, the interest on the study of the etiology, biology and treatment of non-melanoma skin cancer has been growing, mainly due to the world-wide increase of incidence of this illness, as well as due to the destruction of the ozone layer ${ }^{7,13}$.

\section{Host factors}

According to the current literature the male sex is at greater risk of developing skin cancer 10,12,14,15,16. Men develop basal cell cancer two to three times more frequently than women. This may be explained by occupational exposure ${ }^{16}$. Among younger people, the incidence of BCC is equivalent for men and women. After 45 years of age, the incidence is higher among men ${ }^{1}$. In this study, the basal cell cancer was distributed in a similar fashion among the sexes, displaying a slightly higher incidence among women (52\%), with no difference in the age range. This is different from what was found in the literature. Two other studies carried out in Brazil, by Machado et al. ${ }^{11}$ and Bandeira et al. ${ }^{17}$, found a higher incidence of BCC among women, at the rate of 1.7:1 and 1.2:1, respectively. In Machado et al. ${ }^{11}$, they justify the higher incidence among women by the fact that the female population corresponds to $63 \%$ of the studied population. In the population of the present study, $54.4 \%$ are female. These studies show a different characteristic of the incidence of BCC in the Brazilian population, demonstrating a higher incidence in women as compared to other world series. Old age is a well-known risk factor ${ }^{15,18}$. In the patients studied here the higher incidence was between 60 and 80 years of age, corresponding to $59 \%$ of the cases. Elderly individuals have a less efficient immune system and have a diminished DNA repair capacity what increases the risk of developing NMSC ${ }^{18}$. The incidence of non-melanoma skin cancer depends on individual susceptibility. This susceptibility is related to the amount of melanin in the skin and to the capacity of the skin to tan when exposed to ultraviolet radiation. In order to evaluate the susceptibility of the samples used in this study, patients were classified based on their skin color, employing the Fitzpatrick system of phototype. This system classifies individual skin type 
according to the skin reaction to solar exposure ${ }^{9}$. The population under survey was susceptible to BCC, as it was constituted by phototype I patients in 99 cases and type II in 94 cases. These two groups corresponded to $95.5 \%$ of the cases. Nine patients (4.5\%) were photoype III and IV, who correspond in these study to mullatoes and asians. None of them was black. These data are similar to those found in the literature, which show a greater incidence in the white race $^{14}$. None of the patients had any genetic syndrome, such as Xeroderma pigmentosum, Albinism and Nevoid Basall cell carcinoma syndrome, which present a higher risk of incidence of BCC. Though there are no premalignant skin lesions identified for BCC , the presence of actinic keratosis in the clinical exam is an indicator that the individual has been exposed to a significant quantity of ultraviolet $B$ rays ${ }^{3,19}$. This condition is also useful to identify individuals with a high risk of developing specially squamous cell carcinoma, and less frequently, BCC ${ }^{20}$. In a histopathological exam revision study of actinic keratosis (AK), BCC was identified in $4 \%$, what reflects a similar pathogenesis between AK and BCC ${ }^{19}$. In the present study, 88 patients $(43.6 \%)$ presented actinic keratosis in the physical exam, showing skin damage caused by the sun, thus corroborating the notion that $\mathrm{AK}$ is a marker for increased skin cancer risk. Fifty two patients (25.8\%) had a previous history of NMSC, thus demonstrating a higher risk of BCC ${ }^{10,20}$ since the risk of developing NMSC 5 years after the diagnosis of the first one ranges between 36 and $52 \%{ }^{3}$. Conditions that lead to decrease of immunity are another factor that predisposes the incidence of BCC. The decreased mechanism of immunologic vigilance may fail to destroy potentially malignant cells ${ }^{1}$. This condition was identified in $4.5 \%$ of the patients, where seven presented another type of cancer and two were using immunosuppressant drugs (one due to mielofibroplasia and another to a kidney transplant). The risk in the use of such drugs is due to the possible potencialization of the carcinogenic effect of ultraviolet rays ${ }^{1}$.

\section{Environmental factors}

There is ample evidence that once the genetic susceptibility is excluded, the exposition to ultraviolet rays is the most important risk factor in the development of NMSC 6,10,14,21. Besides UVA and UVB rays, which have already been proved to be carcinogenic factors, the UVC, filtered by the ozone layer has a great oncogenic capacity. The ozone layer is being destroyed every day. Mathematical models have estimated an increase of 2 to $4 \%$ of incidence of skin cancer for each $1 \%$ in the reduction of the ozone layer ${ }^{13}$. The relationship of skin cancer and solar radiation has been investigated and the data showed that not only the accumulated quantity, as it was formerly believed, but also the way and the period of exposure increase the risk of basal cell cancer ${ }^{21,22}$. In most cases, the solar exposure accumulated in life has a clearer effect in the occurrence of squamous cell carcinoma than in the occurrence of BCC. On the other hand, intermittent exposure, generally recreational, seems to be more relevant for BCC ${ }^{21}$. This difference may be explained by the type of exposition in certain times of the year, generally at weekends or during yearly vacation weeks, in which cases individuals do not have the opportunity to develop natural skin protection. However, in individuals with continuous occupational exposition, there is time for the skin to develop its natural protection ${ }^{21}$. In the samples surveyed, $77.2 \%$ of the patients mentioned that they had had intense solar exposure throughout their lives. Both occupational (58.3\%), and recreational (41.7\%) exposure were proven to be relevant for the development of BCC. One of the indicators of the relation between an intermittent pattern of exposure and the development of BCC, is the increase in the incidence of BCC on the trunk in the last decade ${ }^{6}$.This pattern of incidence on the trunk was not evident in the present study, where only $6 \%$ of the BCC were located on the trunk. Once the hazards of other environmental factors such as exposure to ionic radiation and to chemicals, either in occupational or therapeutic forms, are well known, there has been a decrease in their influence in the development of CPNM due to the decrease in the number of people exposed ${ }^{1}$. None of the patients on the present study were exposed to ionic radiation or to chemicals.

\section{Characteristics of the BCC}

The majority of the patients presented a single BCC (82.2\%), and the highest number of BCC per patient was 5 , in $0.5 \%$ of the patients. These numbers reveal an average of 1.25 lesions per individual, a low rate when compared to the relation of $1.4^{15}$ and $1.7^{16}$ found in the literature. Patients who have private medical care have an easier access to medical consultations and this may explain the small dimension of the BCC, most of them were in the range of 6 to $15 \mathrm{~mm}$ (58.9\%), only $10.7 \%$ were larger than $15 \mathrm{~mm}$, and the largest BCC was $40 \mathrm{~mm}$. However, the average time between the growth of the BCC and the moment on which the patient looked for medical assistance was 19.8 months, varying between 1 and 120 months. This elapsed time may be explained because the symptoms of these tumors are few. Also, BCC present slow growth, taking one year and longer to duplicate its size. The period of 19.8 months to look for medical help was shown to be shorter when compared to data of public medical care in Brazil, on which the average elapsed time is 48 months ${ }^{15}$. One hundred and sixty seven $(82.7 \%)$ patients had symptoms and the most frequent ones were growth, itching, bleeding and ulcerations. This confirms the data found by Machado et al ${ }^{11}$. It is not easy to define the clinical types of BCC using the macroscopic aspect of the BCC. The accuracy rate is, on average, of 60 to $70 \%{ }^{22}$. The macroscopy of the BCC was divided in accordance with the histological classification found in the literature. The nodular pattern was present in $47 \%$, superficial in 19\%, infiltrative in 9\%, ulcerated in $20 \%$ and pigmented in $9 \%$. Those data confirm the distribution of the histological type found in the literature ${ }^{23}$. The site of occurrence of BCC with the greater incidence was at the head and neck (85\%). This value is similar to those found in the literature that ranges between 73.2 and $85 \%{ }^{6,10,11,14,15,21,24}$. The incidence of BCC in the trunk corresponded to $6 \%$, thus going against the tendency in the last decade when there has been an increase of the incidence of lesions in that area. Castro et al ${ }^{16}$ verified that $40.1 \%$ of the BCC 
occurred in the trunk while $39.7 \%$ were in the cephalic segment. Irebarren et al ${ }^{25}$ also verified a high incidence of BCC in the trunk (33.5\%). The low incidence of BCC in this area may be explained because most of these patients live in the city of São Paulo and usually work with the trunk covered. Biopsy is the best method for the diagnosis of BCC, even though the majority of these tumors presents a typical history and can be recognized through macroscopy ${ }^{3}$. This is the reason why only cases with a histological diagnosis were included in this study. Incisional biopsy is well indicated for larger tumors whereas excisional biopsy is the treatment of choice for smaller lesions ${ }^{3}$. In the cases in which the excisional biopsy using the recommended margins would cause local deformity, the incisional biopsy was made to confirm the diagnosis. The treatment of choice was surgical excision, which was used in $99.4 \%$ of the cases. It is the most common intervention made by surgeons ${ }^{10}$. According to the literature, the cure rate is $95 \%$, getting close to $99 \%$ when the histopathological margins are negative ${ }^{4}$. Radiotherapy was used only in one case $(0.6 \%)$ due to the patient's advanced age and lack of adequate clinical conditions for surgery. The indication of radiotherapy is reserved for selected cases because it does not allow access to histology and control of the margins of the tumor, and it may also cause dermatitis ${ }^{26}$. The purpose of the treatment is the eradication of the BCC with a satisfactory cosmetic result. This is why to determine the exact margin excision is so important ${ }^{10}$. In most cases it is the surgeon who determines the adequate excision margin 4,27. However, it is important to consider the tumor size, the histological type, the anatomic location and the presence of recurrence for a better planning of the area of excision ${ }^{26}$. The margin macroscopically free of tumor recommended for the resection of a BCC varies greatly, from 2 to $10 \mathrm{~mm}$, according to the literature ${ }^{27}$. For tumors smaller than $2 \mathrm{~cm}$, the margin varies between 2 to $5 \mathrm{~mm}^{26}$, with a preference for the margin of $4 \mathrm{~mm}^{4}$. Thus, in this study, the margin was planned according to the dimension of the lesion. Rippey et al ${ }^{23}$ consider margins smaller than $0.38 \mathrm{~mm}$ as a risk factor for recurrence. Kumar et al ${ }^{27}$ reported $4.7 \%$ of incomplete excision using margins of 1 to $2.5 \mathrm{~mm}, 4.1 \%$ with margins of 3 to $4 \mathrm{~mm}$ and $2.9 \%$ with margins of 5 or more $\mathrm{mm}$. The incidence of incomplete excision in the present study was $8 \%$, corresponding to 20 patients. This result is similar to some of the data found in the literature which vary from $0.7 \%$ in Australia ${ }^{28}$, from $4.1 \%$ to $13.7 \%$ in England ${ }^{27}, 4.2 \%$ in Portugal ${ }^{29}$, and $15.4 \%$ in Brazil ${ }^{15}$. Kumar et al..$^{26}$ reported a recurrence rate when the tumor is completely excised of $1 \%$ in 3 years, whereas on average $31 \%$ of the tumors with incomplete excision recurred from 6 to 33 months ${ }^{27}$. When reexcision is performed, this rate drops to $12 \%{ }^{26}$. There is a smaller chance of recurrence when tumor remains at the lateral margin after the BCC removal, when compared to the deep margin or when both are affected ${ }^{30}$. In the present study the affected margins presented a similar distribution, being $40 \%$ on the lateral margin, $35 \%$ on the deep one, and $25 \%$ on both, what differs from the literature that shows a greater compromise of the lateral margin ${ }^{25}$. The predominant histological type of the cases with incomplete excision was nodular (85\%) and only 15\% was diagnosed as morphoeic, whereas the literature search showed a greater incidence of incomplete excision in infiltrative tumors and morphoeic type $^{30}$. Considering the 20 cases that were incompletely excised, thirteen cases (65\%) of the lesions were located on the nose. This high rate may be explained because of the high incidence of BCC in this region (75.7\%). Also, patients who had BCC previously removed may have a higher risk of recurrence. In this study there were 17 cases (6.7\%) previously operated, and though it was expected a more aggressive behavior, these individuals were free of tumor as demonstrated by the histological exam and presented no recurrence in the follow-up. The treatment of incomplete excised tumors is still a controversial matter. There are many studies that support observation and follow up and others that recommend the reexcision ${ }^{28}$. Even though re-operation was recommended to all the patients (20) who presented incomplete excision, only eight of them undertook the surgery and in only one case there was no residual tumor. The remaining 12 patients were scheduled for surgery; and eight of them did not come back for follow up, even though they were fully informed of the risk of recurrence and dissemination. In the cases of histologically proved complete excision of the tumor, there was recurrence in 5 patients (2\%), in the period between 2 and 22 months after the surgery. This value was similar to the data found in the literature $(1 \%)^{27}$. Both cases with incomplete excision and the recurrence cases were re-operated using frozen sections of the margins in the intra-operatory, aiming at the complete resection of the tumor. In all cases the specimen margin was free of tumor. Metastasis in BCC is rare and the incidence varies between 0.00285 and $0.1 \%{ }^{26}$. No case of metastasis or death occurred in the patients surveyed in the present study. Prevention is an important weapon against this tumor. The cost of screening of the whole population is very high. Prevention by early detection could be done by identifying individuals that present the risky characteristics observed in this study. Therefore, the screening of the high risk population would decrease the cost. These patients should also be informed about their risky situation and carry out a professional follow-up throughout their lives.

\section{Conclusions}

The factors related to the development of basal cell cancer which were significantly present in the population surveyed are: older age, white individuals, phototypes I and II, presence of actinic keratosis, previous history of non-melanoma skin cancer and exposure to ultra-violet rays both in recreational and in occupational form. A similar incidence between the genders suggests a specific pattern of the São Paulo city population. Most of the BCC were nodular, preferably located on the nose, with an average size of 9,54 mm, with an average time of evolution of 19,8 months. The surgical treatment employed was effective with a rate of incomplete excision and recurrence similar to those found in the literature.

\section{References}

1. Strom SS, Yamamura Y. Epidemiology of nonmelanoma skin câncer. Clin Plast Surg. 1997 ; 24(4): 627-36.

2. Armstrong BK, Kricker A. Skin cancer. 
Dermatoepidemiology. 1995; 13: 583.

3. Gloster HM, Brodland DG. The epidemiology of skin cancer. Dermatol Surg. 1996; 22: 217-26.

4. Garner KL, Rodney WM. Basal and squamous cell carcinoma. Clin Plast Surg. 1997 ; 24(4): 447-58.

5. Cancer incidence and mortality in Brazil-2003. Available from www.inca.gov.br

6. Zanetti R, Rosso S, Martinez C, Navarro C, Schraub S, Sancho-Garnier H, Franceschi S, Gafa L, Perea E, Tormo MJ, Laurent R, Schrameck C, Cristofolini M, Tumino R, Wechsler J. The multicentre south European study Helios I: skin characteristics and sunburns in basal cell and squamous cell carcinomas of the skin. Br J Cancer. 1996; 73: 1440-6.

7. Raasch B, Maclennan R, Wronski I, Robertson I. Body site specific incidence of basal and squamous cell carcinoma in an exposed population, Townsville, Australia. Mutation Res. 1998; 422: 101-6.

8. Kaldor J, Shugg D, Young B, Dwyer T, Wang YG. Nonmelanoma skin cancer: ten years of cancer-registry-based surveillance. Int J Cancer. 1993; 53: 886-91.

9. Fitzpatrick TB, Sober AJ. Sunlight and skin cancer. N Engl J Med.1985; 313: 818.

10.Lear JT, Smith AG. Basal cell carcinoma. Postgrad Med J. 1997; 73: 538-42.

11.Machado CDS, Fagundes DS, Sender F, Saraiva GL, Paschoal LHC, Costa MCC, Cunha RMES, Carazzato SG. Neoplasias malignas cutâneas: estudo epidemiológico. An Bras Dermatol. 1996 ; 71(6): 479-84.

12.Nasser N. Incidência de câncer de pele em Blumenau/ SC - 1980-1990. An Bras Dermatol. 1993; 68(3): 77-8.

13.Diffey BL. Stratospheric ozone depletion and the risk of non-melanoma skin câncer in a British population. Phys Med Biol. 1992; 37(12): 2267-79.

14.Wennberg AM. Basal cell carcinoma: new aspects of diagnosis and treatment. Acta Derm Venereol. 2000;(Suppl 209): 5-25.

15.Magliavacca A, Guimarães JR, Melo LL, Vecino MCA, Araújo HM. Carcinoma basocelular: revisão de 381 casos no Hospital de Clínicas de Porto Alegre. Rev HCPA. 1990; 10(2): 95-8.

16.Castro LGM, Toyama CL, Gomes AP, Freire MA, Britto TF. Câncer de pele em clínica particular em São Paulo SP. An Dermatol. 1996 ; 71(6): 471-6.

17.Bandeira AM, Bandeira V, Silva JF, Mazza E. Carcinomas basocelulares: estudo clínico e anatomopatológico de 704 tumores. An Bras Dermatol. 2003 ; 78(1): 23-34.

18.Wei Q, Matanoski GM, Farmer ER, Hedayati MA, Grossman L. DNA repair and aging in basal cell carcinoma: A molecular epidemiology study. Proc Natl Acad Sci USA. 1993; 90: 1614-8.

19.Carag HR, Prieto VG, Yballe LS, Shea CR. Demonstration of additional pathological findings in biopsy samples initially diagnosed as actinic keratosis. Arch Dermatol. 2000 ; 136: 471-5.

20.Schwartz RA. The actinic keratosis: a perspective and update. Dermatol Surg. 1997; 23: 1009-19.

21.Rosso S, Zanetti R, Martinez C, Tormo MJ, Schraub S, Sancho-Garnier H, Franceschi S, Gafa L, Perea E, Navarro C, Laurent R, Schrameck C, Talamini R, Tumino R, Wechsler J. The multicentre south European study Helios II: different sun exposure patterns in the aetiology of basal cell carcinomas of the skin. Br J Cancer. 1996; 73: 1447-54.

22.Kricker A, Armstrong BK, English DR, Heenan PJ. Does intermittent sun exposure cause basal cell carcinoma? A case-control study in Western Australia. Int J Cancer. 1995; 60: 489-94.

23.Rippey JJ. Why classify basal cell carcinomas? Histopathology.1998; 32: 393-8.

24.Levi F, Vecchia C, Te VC, Mezzanotte G. Descriptive epidemiology of skin cancer in the Swiss Canton of Vaud. Int J Cancer. 1988; 42: 811-6.

25.Iribarren O, San Martin J, Alcazar A, Larenas E, Fischer J, Gallegos E.Carcinoma basocelular: epidemiologia y factores de riesgo. Rev Chil Cir. 1995 ; 47(2): 123-7.

26.Goldberg DP. Assessment and surgical treatment of basal cell skin cancer. Clin Plast Surg. 1997; 24(4): 673-86.

27.Kumar P, Watson S, Brain NA, Davenport PJ, McWilliam LJ, Banerjee SS. Incomplete excision of basal cell carcinoma: a prospective multicentre audit. Br J Plast Surg. 2002; 55: 616-22.

28.Emmett AJJ, Bradbent GG. Basall cell carcinoma in Queensland. Aust N Z J Surg. 1981; 51: 576-90.

29.Ferreira PJS, Correia PM. Basaliomas incompletamente excisados: significado prognóstico a curto prazo. An Bras Dermatol. 1998; 73(1): 7-10.

30.Grabski WJ, Salasche SJ. Positive surgical excision margins of a basal cell carcinoma. Dermatol Surg. 1998; 24:921-4.

\section{Correspondence:}

Roberta Lopes Bariani

Rua Inhambu, 332

04520-010 São Paulo-SP Brazil

r.bariani@uol.com.br
Conflict of interest: none Financial source

Received: October 02, 2005

Review: November 10, 2005

Accepted: December 18, 2005

\section{How to cite this article:}

Bariani RL, Nahas FX, Barbosa MVJ, Farah AB, Ferreira LM. Basal cell carcinoma: an updated epidemiological and therapeutically profile of an urban population. Acta Cir Bras. [serial on the Internet] 2006 Mar-Apr;21(2). Available from URL: http://www.scielo.br/acb 